\title{
Correction to: Preliminary use of Polygonum minus Linn. leaf extract on growth performance, feed utilization, and some hematological indices of Anabas testudineus (Bloch, 1792)
}

\author{
${\text { Paiboon } \text { Panase }^{1} \text { (D) } \cdot \text { Prameda Tipdacho }}^{1}$
}

Published online: 6 November 2017

(C) Springer-Verlag London Ltd. 2017

\section{Correction to: Comp Clin Pathol}

https://doi.org/10.1007/s00580-017-2566-4

The original version of this paper unfortunately captured the equation incorrectly and is given below:

\section{Equations of growth parameter}

$\mathrm{WG}=$ final weight $(\mathrm{g})$-initial weight $(\mathrm{g})$

$\mathrm{ADG}=[$ final weight $(\mathrm{g})$-initial weight $(\mathrm{g})] /$ Days

$\mathrm{SGR}=[\{$ Ln final weight $(\mathrm{g})-\operatorname{Ln}$ initial weight $(\mathrm{g})\} /$ Days $] \times 100$

$\mathrm{FCR}=$ total feed fed $(\mathrm{g}) /$ weight gain $(\mathrm{g})$

$\mathrm{FE}=$ weight gain $(\mathrm{g}) /$ total feed $(\mathrm{g})$

PER = wet weight gain $(\mathrm{g}) /$ crude protein fed

$\mathrm{SR}=[$ Number of survived fish/Initial number of fish $] \times 100$

The original article has been corrected.

The online version of the original article can be found at https://doi.org/ 10.1007/s00580-017-2566-4

Paiboon Panase

tong33_panamagigas@hotmail.com

Fisheries Division, School of Agriculture and Natural Resources,

University of Phayao, Phayao 56000, Thailand 